\title{
PENINGKATAN PEMAHAMAN DEFINISI LOGARITMA MELALUI PENGGUNAAN ILUSTRASI GAMBAR
}

\author{
Neneng Hesti Handayani Ningsih \\ SMA Negeri 15 Bandung \\ nenenghesti274@gmail.com
}

\begin{abstract}
ABSTRAK
Realitas proses pembelajaran matematika yang terjadi di lapangan pada umumnya senantiasa menyulitkan dan memusingkan siswa. Hal ini sangat berdampak pada minat dan hasil pembelajaran siswa. Tujuan penelitian ini adalah untuk mengetahui pemahaman konsep belajar dan mengetahui respon siswa selama proses pembelajaran berlangsung. Penelitian dilaksanakan di SMA Negeri 15 Bandung, di kelas XII Bahasa, jumlah siswa 20 orang yang terdiri dari 6 orang siswa pria dan 14 orang siswa wanita. Metodenya adalah penelitian tindakan kelas (PTK) dengan desain penelitian terdiri dari 4 (empat) tahap yaitu: perencanaan, pelaksanaan, observasi dan refleksi. Penelitian dilakukan 2 siklus. Hasil refleksi siklus ke 1 yang digunakan sebagai bahan rencana tindakan siklus ke 2 agar pada siklus ke 2 proses pembelajaran lebih terarah. Hasil penelitian disimpulkan bahwa: Penggunaan media ilustrasi gambar dapat meningkatkan pemahaman konsep definisi logaritma. Hasil angket dan wawancara dengan siswa menunjukkan semua siswa merasa senang dengan proses pembelajaran, semua siswa tertarik dengan berdiskusi dengan teman, semua siswa menyatakan peran guru membantu dalam bekerja secara mudah dan interaktif, sebagian besar menganggap soal yang diberikan tidak terlalu sulit, sebagian besar siswa lebih aktif, dan semua siswa senang menyelesaikan soal logaritma dengan menggunakan ilustrasi gambar.
\end{abstract}

Kata Kunci: ilustrasi gambar, definisi logaritma, pemahaman konsep.

\begin{abstract}
The reality of the process of learning mathematics that occurs commonly in the field it's complicating dan confusing students. This is very impact on interest and student learning outcomes. The purpose of this study is to know the understanding of learning concepts and to know the response of students during the learning process. The research was located at SMA Negeri 15 Bandung, in class XII-Language, the number of students 20 people consisting of 6 male students and 14 female students. Classroom action research method with research design consists of 4 (four) stages: planning, implementation, observation and reflection. The study was conducted 2 cycles. Reflection results of the 1st cycle used as the 2nd cycle's plan material in order to the 2nd cycle of learning process more focused. The results concluded that: The use of image illustration media can improve the concept of logarithm definition. The results of questionnaires and interviews with students showed all students were happy with the learning process, all students interested in discussing with friends, all students declared the role of teachers help in working easily and interactively, most assume the given problem is not too difficult, most students more active, and all students love to solve the problem of logarithm by using illustration of the picture.
\end{abstract}

Keywords: image illustration, logarithm definition, concept comprehension. 


\section{PENDAHULUAN}

Matematika adalah suatu mata pelajaran yang dianggap sebagian besar siswa sangat menyulitkan dan memusingkan, hal ini sangat berdampak pada minat dan hasil pembelajaran siswa pada mata pelajaran tersebut. Iklim pembelajaran matematika menjadi "kering”, dikarenakan pembelajaran matematika yang menekankan kepada materi atau teori tanpa memperhatikan aspek-aspek pedagogik. Proses pembelajaran yang menyenangkan dapat dijadikan sebagai suatu hiburan, dan bukan lagi menjadi hal yang menakutkan bagi siswa. Sehingga kemasan pembelaja-ran yang menarik pastilah akan mendapat perhatian yang serius dari para siswa, Saputra (2013: 219).

Fenomena umum yang dipaparkan di atas, terjadi juga di SMAN 15 Bandung, berdasarkan pengalaman penulis mengajar matematika selama ini setelah dievaluasi khususnya pada materi tentang definisi logaritma, hasil yang diperoleh siswa kelas XII program bahasa tahun 2016-2017 rata-ratanya 39,7 dengan nilai Kriteria Ketuntasan Minimal (KKM) 70,00. Agar proses pembelajaran berhasil mencapai KKM yang sudah ditetapkan maka seorang guru harus kreatif, harus dapat memilih media pembelajaran yang relevan dengan materi pokok yang diajarkan serta sesuai dengan karakteristik siswa, sehingga dapat meningkatkan minat, motivasi dan prestasi belajar peserta didik. Berdasarkan pengalaman penulis, Penggunaan media ilustrasi gambar dapat memberikan pengaruh kepada sebagian besar siswa untuk peningkatan pemahaman konsep definisi logaritma dan prestasi belajar peserta didik. Oleh karena itu penulis menggunakan media ilustrasi gambar pada pembelajaran definisi logaritma yang diharapkan dapat menyelesaikan masalah di atas. Menurut Saputra (2015a: 78)," Pembelajaran yang berdayaguna atau berpusat pada masalah digerakkan oleh keinginan bawaan peserta didik untuk menyelidiki secara pribadi situasinya". Kemandirian belajar siswa bisa dicapai jika dalam proses pembelajaran memberi kesempatan terbuka bagi peserta didik untuk belajar secara mandiri, Saputra (2017b: 117). Selain itu pendekatan saintifik sebagai salah satu cara peserta didik untuk menyelesaikan masalah yang dihadapinya. Pendekatan Saintifik sebagai pembelajaran alternatif selanjutnya diasumsikan dapat memperbaiki tingkat self efficacy siswa tingkat awal.

Sebagai konsekuensinya guru harus mampu mengembangkan pengelolaan pembelajaran yang interaktif dan memberikan kesempatan kepada semua siswa untuk berperan serta terhadap proses belajar mereka yang merupakan wujud dari pengalaman belajarnya. Berdasarkan permasalahan tersebut di atas, dengan menggunakan media 
ilustrasi gambar siswa memahami konsep definisi logaitma dan respon belajar siswa dapat meningkat?". Tujuan penelitian ini untuk mengetahui pemahaman konsep peserta didik dalam pembelajaran definisi logaritma dan mengetahui respon siswa setelah pembelajaran definisi logaritma dengan menggunakan media ilustrasi gambar berlangsung.

Selain kemampuan guru mengelola pembelajaran, dengan sistem pendidikan yang baik diharapkan muncul generasi penerus bangsa yang berkualitas dan mampu menyesuaikan diri untuk hidup bermasyarakat, berbangsa dan bernegara. "The Director General of Teachers and Education Personnel (GTK) reported that based on the results of Teacher Competency Test (UKG) administered at the end of 2015, the average scores was 53.02. The competencies tested are professional competence and pedagogic competency. Based on the data, it is still necessary to improve the quality of teachers in Indonesia." (Darta \& Saputra, 2018: 2).

\section{Stategi Pemecahan Masalah dengan Membuat Gambar}

Tokoh utama tentang Strategi pemecahan masalah yaitu Polya (2008: 58), salah satu stategi pemecahan masalah dengan membuat gambar. Stategi ini membantu siswa untuk mengungkapkan informasi yang terkandung dalam masalah sehingga hubungan antar komponen dalam masalah tersebut dapat terlihat dengan jelas. Pada saat guru mencoba mengajarkan strategi ini, penekanan perlu dilakukan bahwa gambar yang dibuat tidak perlu sempurna, terlalu bagus atau terlalu detail. Hal yang perlu digambar adalah bagian-bagian yang terpenting yang diperkirakan mampu memperjelas permasalahan yang dihadapi. Untuk membawa tujuan pembelajaran ke arah yang dapat meningkatkan kemampuan pemecahan masalah, pembelajaran harus lebih menekankan pada pemecahan masalah secara autentik seperti masalah yang terjadi dalam kehidupan sehari-hari (Saputra, 2015b: 501). Sebagai contoh diberikan soal: Tentukan nilai a pada persamaan: ${ }^{3} \log 81=a$.

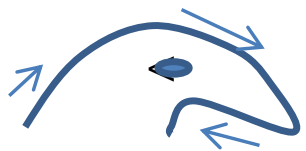
Pembahasan:

$$
\begin{aligned}
& { }^{3} \log 81=\mathrm{a} \leftrightarrow 3^{\mathrm{a}}=81 \\
& 3^{a}=3^{4}
\end{aligned}
$$$$
\mathrm{a}=4
$$

Dengan menggunakan ilustrasi gambar paruh burung, Langkah pertama tarik garis lengkung dari angka 3 ke a (3 dipangkatkan dengan a) sama dengan 81. Maka diperoleh nilai $\mathrm{a}=4$. Sebagai contoh, dengan menggunakan ilustrasi gambar paruh buruntg, siswa 
diharapkan lebih mudah memahami definisi logaritma (mengubah bentuk logaritma ke dalam bentuk bilangan berpangkat).

Ilustrasi diperlukan untuk menyertai suatu kontekstual. Peranannya adalah untuk memotivasi, menggambarkan situasi, menyiapkan informasi, mengidentifikasi action , mensuplai model, dan mengkomunikasikan solusi, serta strategi untuk solusi (Panhuizen, 1996). Selanjutnya De Porter, B (2003:67) menyatakan bahwa: “ Sebuah gambar lebih berarti dari seribu kata. Jika anda menggunakan alat peraga dalam situasi belajar, akan terjadi hal yang menakjubkan bukan hanya mengawali proses belajar dengan cara merangsang modalitas visual. Alat peraga juga secara harafiah menyalakan jalur saraf seperti kembang api di malam tahun baru. Beribu ribu asosiasi tib-tiba diluncurkan kedalam kesadaran, kaitan ini menyediakan konteks yang kaya untuk pembelajaran yang baru" (Reardon \& De Porter, 2003: 67).

Alat peraga membantu daya ingat, alat bantu adalah benda yang dapat mewakili suatu gagasan. Alat bantu tidak hanya membantu pembelajaran visual, tetapi dapat pula membantu modalitas kinestetik mendapatkan "rasa" yang lebih baik dari ide yang anda sampaikan. (Reardon \& De Porter, 2003:70 ).

\section{METODE PENELITIAN}

Penelitian ini adalah Penelitian Tindakan Kelas ( PTK ) yang dapat dilakukan sesuai dengan keadaan dan jadwal pelajaran di sekolah. Pelaksanaan pembelajaran melalui proses pengkajian berdaur yang terdiri dari 4 tahap yaitu : perencanaan, pelaksanaan, observasi dan refleksi (Patrianto, Sa 'dijah, \& Qohar, 2012). Penelitian dilakukan 2 siklus. Pelaksanaan proses pembelajaran di kelas XII program Bahasa semester 1 tahun pelajaran 2017-2018 pada SMAN 15 Bandung, jumlah siswa 20 orang yang terdiri dari 6 orang siswa pria dan 14 orang siswa wanita.Lokasi SMAN 15 berada di jl. Sarimanis I Sarijadi Bandung

\section{HASIL DAN PEMBAHASAN}

Berdasarkan Perolehan Nilai Pre-Test dan Post Test dari jumlah siswa sebanyak 20 orang nilai rata-rata pre-test adalah 24,3 dan belum tuntas seluruhnya. Sedangkan hasil nilai rata-rata post-test adalah 78 dan daya serap $75 \%$, dari hasil evaluasi post-test tersebut dapat dikesimpulan bahwa pembelajaran pada tindakan pertama telah tuntas sebanyak 15 
orang, dan 5 orang siswa perlu melaksanakan kegiatan remedial.seperti terlihat pada Gambar 1.

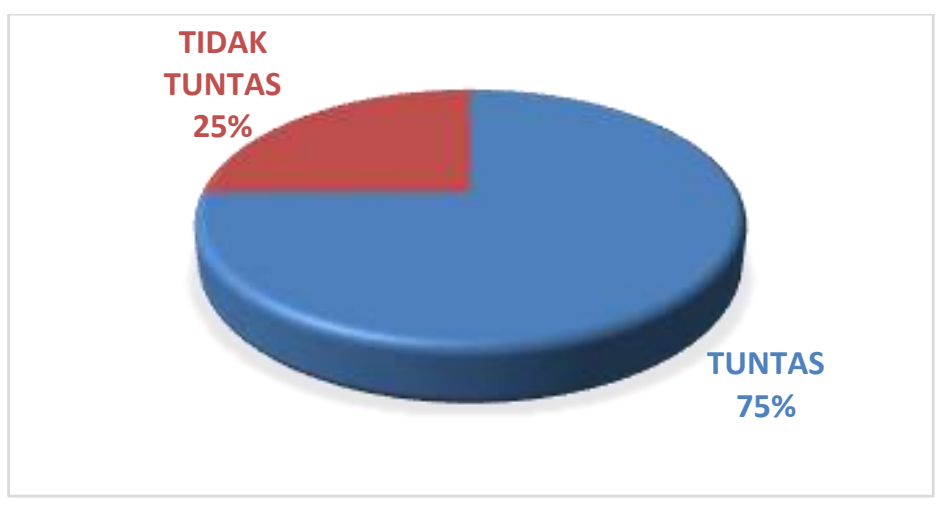

Gambar 1. Ketuntasan Belajar Post-Test

Pendapat siswa tentang proses pembelajaran siswa sangat tertarik dan sebagian besar siswa tertarik dengan pembelajaran logaritma dengan menggunakan media ilustrasi gambar. Dan tidak seorangpun yang menganggap proses pembelajaran dengan pembelajaran logaritma dengan menggunakan media ilustrasi gambar tidak menarik dan tidak tahu. Pendapat siswa tentang materi pelajaran, ternyata sebagian kecil sangat tertarik, dan ternyata hampir semua siswa sangat tertarik pada materi pelajaran logaritma dengan menggunakan media ilustrasi gambar. Tak seorangpun menganggap tidak tertarik dan tidak tahu dengan materi pelajaran logaritma dengan menggunakan media ilustrasi gambar.

Pendapat siswa tentang kesempatan berdiskusi dengan teman sekelompok atau sekelas memudahkan siswa menyelesaikan soal, ternyata seperempat siswa sangat tertarik dan sebagian besar siswa tertarik dengan berdiskusi dengan teman sekelompok atau sekelas memudahkan siswa menyeesaikan soal logaritma dengan menggunakan media ilustrasi gambar. Pendapat siswa tentang peran guru dalam membantu siswa untuk bekerja secara mudah dan interaktif, sebagian kecil peran guru cukup membantu dan ternyata hampir semua siswa menyatakan peran guru membantu siswa untuk bekerja secara mudah dan interaktif pada proses pembelajaran pemahaman definisi logaritma dengan menggunakan ilustrasi gambar.

Pendapat siswa tentang tingkat kesulitan soal-soal yang diberikan, ternyata sebagian kecil siswa menganggap sangat sulit soal-soal yang diberikan. Sedangkan sebagian besar siswa menganggap sulit soal yang diberikan. Sebagian besar (40\%) siswa menganggap tidak sulit soal yang diberikan dan sebagian kecil (5\%) siswa menganggap tidak tahu tentang soal-soal yang diberikan pada pembelajaran pemahaman definisi logaitma dengan menggunakan media ilustrasi gambar. Pendapat siswa tentang keaktifan dalam proses pembelajaran dibanding sebelumnya, ternyata sebagian besar siswa 
menyatakan lebih aktif dalm pembelajaran dibanding dengan biasanya. Sebagian besar siswa juga menyatakan tidak terlalu aktif. Sedangkan Tak seorangpun siswa menyatakan tidak aktif, serta satu orang yang menyatakan tidak tahu. Pendapat siswa tentang kesenangan dalam proses pembelajaran dengan menggunakan media ilustrasi gambar, sebagian besar siswa menyatakan sangat senang, Sedangkan seperempat siswa menyatakan merasa senang dengan pembelajaran pemahaman definisi logaritma dengn menggunakan media ilustrasi gambar.

Wawancara dilakukan terhadap beberapa orang siswa mewakili kelompok atas, siswa kelompok sedang, dan siswa kelompok bawah. Hasil wawancara yang dilaksanakan pada akhir siklus 2. Berdasarkan pertanyaan 1: Bagaimana pendapat kamu tentang penggunaan ilustrasi gambar dalam pemahaman definisi logaritma yang telah kamu ikuti? ternyata jawaban semua siswa tertarik dengan proses pembelajaran, ketertarikan semua siswa itu karena pada pembelajaran tersebut membuat lebih aktif, lebih efektif, lebih kreatif, tidak jenuh, lebih santai, mudah diingat, dan mudah dimengerti.bahkan ada satu siswa yang berkebutuhan khusus (ADHD) merasa tertarik dikarenakan siswa tersebut lebih mudah mengingat materi melalui gambar dan media tertentu

Berdasarkan pertanyaan 2: Bagaimana kesan kamu selama selama proses pemahaman definisi logaritma dengan menggunakan media ilustrasi gambar? Apakah kamu merasa senang? Berikan jawaban dan alasan? ternyata jawaban dari semua siswa yang diwawancarai merasa senang dengan pembelajaran logaritma dengan menggunakan ilustrasi gambar. Kesenangan semua siswa itu karena pada pembelajaran tersebut membuat lebih cepat mengerti, merasa tidak terbebani, atau membuat lebih bebas, santai , tidak bosan, unik dan hiburan. Jawaban dari siswa yang berkebutuhan khusus merasa.

senang karena bisa melihat bagaimana kawan sekelas saya menggambar. Merasa senang, karena gurunya rame dan ngajarnya pelan-pelan jadi saya mengerti, Merasa senang, karena lebih bisa dipahami dengan menggunakan gambar dan merasa senang, jadi lebih tahu lagi caranya. Berdasarkan pertanyaan 3 : Bagaimana pendapat kamu tentang soal-soal yang diberikan? Apakah mengalami kesulitan? Berikan jawaban dan alasan?, ternyata jawaban dari dari beberapa beberapa siswa yang diwawancarai merasa soal-soal yang diberikan tidak terlalu sulit, karena ilustrasi gambar dapat membantu dalam menyelesaikan soal-soal logaritma. Jawaban dari siswa yang berkebutuhan khusus, sedikit mengalami kesulitan dalam menjawab soal soal logaritma. Namun menurut siswa tersebut dapat diatasi karena guru yang baru (bu Neneng Hesti), dapat mengajari saya yang 
memiliki gangguan konsentrasi (ADHD) dengan baik. Berdasarkan pertanyaan 4 : Bagaimana pendapat kamu tentang peran guru selama proses pembelajaran? Apakah sudah cukup membantu? Bagaimana seharusnya guru berperan? berikan jawaban dan alasan?, ternyata jawaban dari beberapa siswa yang diwawancarai merasa peran guru sangat membantu, karena guru sebagai motivator dan fasilitator bukan dictator.

Hasil wawancara dengan beberapa orang siswa yang mewakili kelompok atas, sedang, dan bawah adalah sebagai berikut: 1) Siswa tertarik dengan media ilustrasi gambar pada pembelajaran logaritma ini, karena media ilustrasi gambar dapat membangkitkan keinginan dan minat baru, membangkitkan motivasi rangsangan kegiatan belajar dan bahkan membawa pengaruh psikologis terhadap siswa, serta membantu keefektifan proses pembelajaran dan penyampaian pesan da nisi pembelajaran pada saat itu. 2) Siswa merasa senang dengan media ilustrasi gambar pada pada pembelajaran logaritma ini, karena media ilustrasi gambar dapat membawa dan membangkitkan rasa senang dan gembira bagi siswa dan mempengaruhi semangat mereka membantu memantapkan pengetahuan pada benak para siswa serta menghidupkan proses pembelajaran. 3) Siswa menanggap soal-soal yang diberikan pada pembelajaran logartma dengan menggunakan media ilustrasi gambar tidak terlalu sulit dan dapat diselesaikan dengan benar, karena media ini dapat membuat bahan pengajaran akan lebih jelas maknanya sehingga dapat lebih dipahami oleh siswa dan memungkinkan menguasai dan mencapai tujuan pembelajaran. 4) Media ilustrasi gambar dapat membuat metode mengajar akan lebih bervariasi, tidak semata-mata komunikasi verbal melalui penuturan kata-kata guru, sehingga siswa tidak bosan dan guru tidak kehabisan tenaga. 5) Media ilustrasi gambar dapat membuat siswa lebih banyak melakukan kegiatan belajar sebab tidak hanya mendengarkan guru, tetapi juga aktifitas lain seperti menggambar dengan penuh makna. 6) Media ilustrasi gambar dapat memberikan pengalaman nyata yang dapat menumbuhkan siswa berusaha sendiri atau mandiri, karena pada umumnya setiap siswa membuat ilustrasi gambar yang berbeda. 7) Media ilustrasi gambar dapat membantu daya ingat, dapat mewakili suatu gagasan, tidak hanya membantu visual, tetapi dapat pula membantu modalitas kinestetik. Siswa yang kinestetik mendapatkan "rasa" yang lebih baru dari ide yang siswa sampaikan.

\section{Refleksi Siklus 1}

Data dari hasil observasi yang dilakukan dengan bantuan rekan guru matematika, pembelajaran dengan menggunakan media ilustrasi gambar dilakukan observasi pada 
setiap tindakan. Observasi terhadap kesiapan guru dalam mengajar pada tindakan pertama adalah dapat ditafsirkan bahwa pembelajaran logaritma dengan menggunakan ilustrasi gambar berjalan dengan baik, kecuali pemberian soal pre test/post test terlalu mudah, soal tersebut kurang menantang serta kurangnya penekanan pada saat guru mengajarkan media ini, bahwa gambar yang dibuat tidak perlu sempurna, terlalu bagus atau terlalu detail. Hal yang perlu digambar adalah bagian bagian terpenting yang diperlukan mampu memperjelas permasalahan yang dihadapi.

Observasi terhadap siswa pada tindakan pertama menunjukkan bahwa siswa mengerjakan soal secara indvidu sudah berjalan baik, kecuali interaksi antar siswa kurang karena penugasan soal secara individual. Observasi terhadap kesiapan guru dalam mengajar pada tindakan kedua adalah dapat ditafsirkan bahwa pembelajaran logaritma dengan media ilustrasi gambar sangat baik, Karen seorang guru dituntut agar dapat membuat media pembelajaran sederhana, tuntutan yang tidak kalah pentingnya adalah penekanan pada saat guru menggunakan media ilustrasi gambar ini, bahwa hal-hal yang perlu digambar adalah bagian bagian terpenting yang diperlukan serta mampu memperjelas permasalahan yang dihadapi.

\section{Pelaksanaan Siklus kedua}

Pada siklus kedua ini, pembelajaran dirancang berdasarkan hasil refleksi pada siklus kesatu, siswa sudah dikelompokkan kedalam empat kelompok, masing-masing kelompok terdiri dari 5 orang dengan memperhatiakan tingkat kemampuan siswa. Siklus kedua dilaksanakan pada hari senin 29 januari 2018 pukul 12.45 - 14.05. kegiatan awal dimulai dengan pengkondisian kelas, pengecekan kehadiran, pemberian motivasi dan apersepsi, penyampaian tujuan pembelajaran dan penyampaian teknik penilaian.

Setelah siswa duduk dalam kelompoknya, kegiatan dimulai dengan guru membagikan soal yang berjenjang, dari soal seerhana sampai soal seleksi masuk perguruan tinggi. Proses pengerjaan soal dengan menggunakan media ilustrasi gambar dan menggunakan model pembeljaran Numbered Heads Together (NHT). Langkah-langkah model pembelajaran NHT: 1) Siswa dibagi dalam kelompok, setiap siswa dalam kelompok mendapat npmor kepala, 2) Guru memberikan tugas dan masing-masing kelompok mengerjakannya, 3) Kelompok mendiskusikan jawaban yang benar dan memastikan tiap anggota kelompok dapat mengerjakannya/mengetahui jawabannya, 4) Guru memanggil salah satu nomor kepala siswa dan siswa dengan nomor yang dipanggil melaporkan hasil 
kerjasama mereka, 5) Tanggapan dari teman yang lain, kemudian guru menunjuk nomor kepala yng lainnya, 6) Kesimpulan.

Proses pembelajaran pada siklus kedua semua siswa aktif karena pembelajaran dilakukan secara kelompok, sehingga terjadi interaksi antar siswa sangat baik dibandinkan pada siklus kesatu. Evaluasi dilaksanakan setelah selesai pada pelaksanaan siklus kedua yang diikuti oleh 20 orang siswa kelas XII BAHASA, dengan hasil penilaian yaitu kesimpulan dari hasil rata-rata evaluasi dari jumlah siswa sebanyak 20 orang adalah 93,50 dan daya serap $100 \%$, dari hasil evaluasi tersebut, nilai rata-rata naik 15,51, daya serap naik $4 \%$, dapat disimpulkan bahwa pembelajaran pada tindakan kelas kedua telah tuntas.

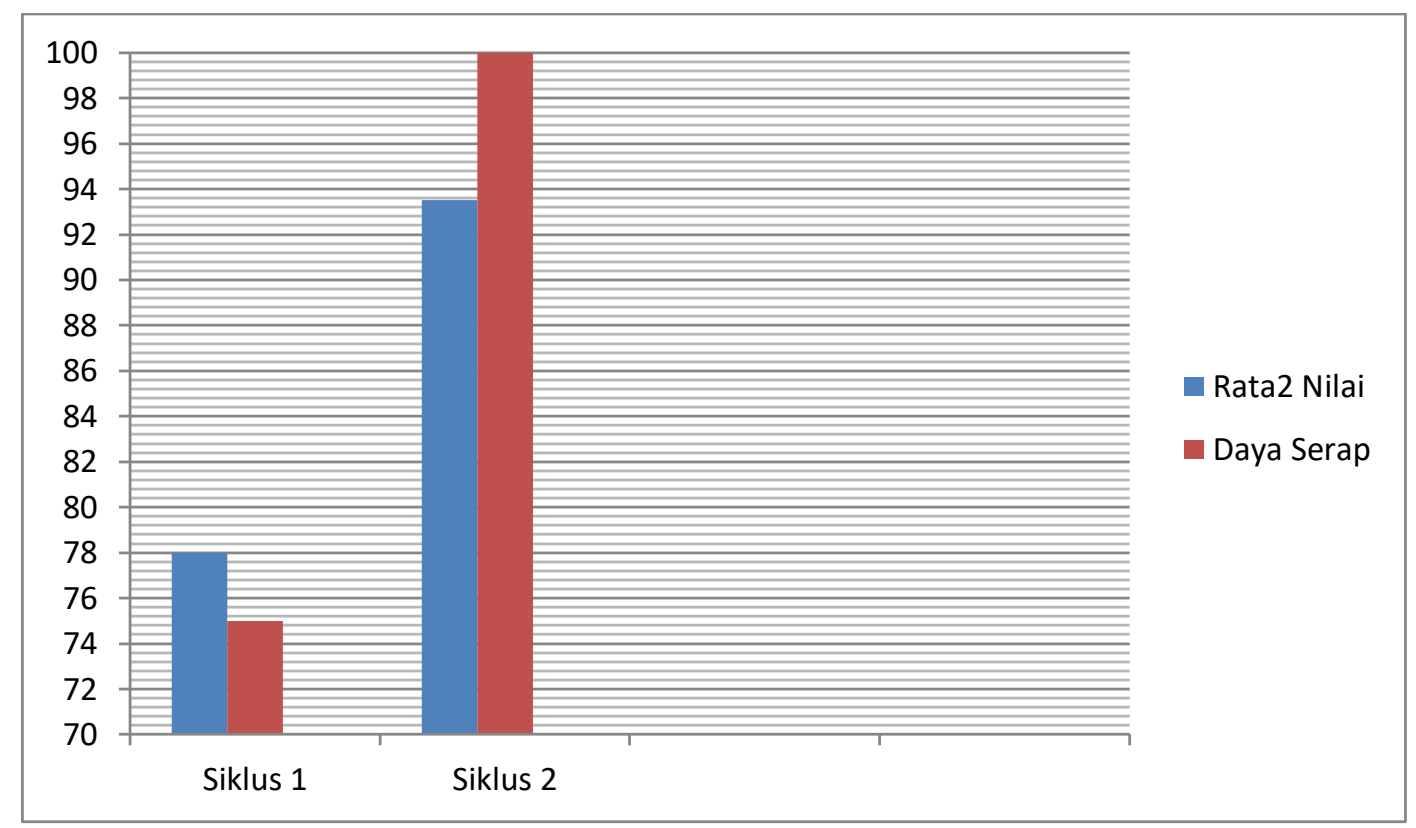

Gambar 2. Hasil Evaluasi

Sesuai dengan pendapat tokoh utama tentang Strategi pemecahan masalah yaitu George Polya, salah satu stategi pemecahan masalah dengan membuat gambar. Stategi ini membantu siswa untuk mengungkapkan informasi yang terkandung dalam masalah sehingga hubungan antar komponen dalam masalah tersebut dapat terlihat dengan jelas

Berdasarkan hasil evaluasi diagram tersebut diatas, penulis dapat menafsirkan, bahwa hasil pembelajaran logaritma dengan menggunakan media ilustrasi gambar telah berhasil meningkatkan pemahaman definisi logaritma pada siswa kelas XII BAHASA.

Berdasarkan hasil evaluasi siklus 1 dan siklus 2, hampir semua siswa dapat menyelesaikan soal dengan benar, membuat ilustrasi gambar sebagai solusi yang menarik dan berbagai alasan lainnya seperti terlihat pada hasil angket. Pembelajaran logaritma dengan menggunakan ilustrasi gambar dapat meningkatkan pemahaman definisi logaritma siswa kelas XII BAHASA di SMA Negeri 15 Bandung. 
Data angket dan wawancara, serta hasil observasi menunjukkan proses pembelajaran sesuai dengan tujuan penelitian yaitu siswa dapat meningkatkan pemahaman definisi logaritma, hal ini terlihat dari semangat siswa dalam mengikuti pembelajaran baik secara individu maupun secara berkelompok. Pembelajaran logaritma menggunakan media ilustrasi gambar telah berhasil meningkatkan hasil belajar siswa. Data diambil dari jawaban siswa pada soal-soal evaluasi menunjukkan bahwa tingkat kemampuan dan keterampilan siswa untuk menjawab dengan benar untuk mencapai nilai rata-rata post test $=77,99$ (Siklus 1) dan evaluasi $=93,5$ (Siklus 2), sedangkan daya serap post test $75 \%$ dan daya serap evaluasi $100 \%$. Dalam penelitian ini, tentunya siswa akan membandingkan pembelajaran matematika yang dialami sebelumnya. Awal dari kegiatan pembelajaran dengan mencari soal-soal logaritma yang mudah. Hampir semua siswa belajar lebih semangat karena semua siswa termotivasi untuk dapat menyelesaikan soal-soal Ujian Nasional dengan benar. Siswa dikondisikan untuk belajar ketika mereka memproses suatu informasi sedemikian sehingga menjadi bermakna sesuai dengan kerangka berfikir yang mereka miliki. Hal ini berkaitan dengan penggunaan media ilustrasi gambar dalam arti sesungguhnya dapat dipahami siswa.

Masalah yang diambil sebagai contoh pada soal post test dan evaluasi mengenai logaritma. Siswa memahami dan mengerti contoh soal yang dikemukakan sehingga mereka dapat belajar dan mengerjakan soal-soal logaritma, misalnya soal seleksi ke perguruan tinggi, dan ini membuat mereka senang dan mendorong mereka beljar dengan seefektif mungkin. Sebagai indikator tentang reaksi siswa tentang pembelajaran dengan menggunakan media ilustrasi gambar dapat dilihat pada data wawancara dan observasi.

Materi pada penelitian ini adalah mengubah bentuk pangkat ke bentuk logaritma dan sebaliknya, melakukan operasi aljabar, menyederhanakan bentuk aljabar yang memuat logaritma, membuktikan sifat-sifat logaritma, menunjukkan kegiatan individu / kelompok dan bekerja sama. Sesuai dengan pendapat De Porter (2003:67) menyatakan bahwa "Sebuah gambar lebih berarti dari seribu kata. Jika anda menggunakan alat peraga dalam situasi belajar, akan terjadi hal yang menakjubkan bukan hanya mengawali proses belajar dengan cara merangsang modalitas visual. Alat peraga juga secara harafiah menyalakan jalur saraf seperti kembang api di malam tahun baru. Beribu ribu asosiasi tib-tiba diluncurkan kedalam kesadaran, kaitan ini menyediakan konteks yang kaya untuk pembelajaran yang baru" (2003: 67). 
Penggunaan media yang dapat diterima siswa membuat mereka dapat menemukan konsep tanpa harus langsung bekerja secara abstrak. Dengan belajar pada apa yang dimengertinya membuat siswa senang, sesuatu yang jarang didapat pada pembelajaran dengan tidak menggunakan media ilustrasi gambar. Sebagai contoh tentang kesan terhadap penggunaan media pada pembelajaran dapat dilihat pada hasil wawancara dan observasi. Materi yang diberikan memungkinkan siswa menjawab dengan berbagai gambar untuk menjawab soal-soal yang diberikan sesuai dengan tingkat ketrampilan dan pengetahuan mereka sendiri.

Tahapan ini tidak ada pada pembelajaran konvensional yang selama ini penulis gunakan dalam mengajar matematika. Selama ini pembelajaran mengharuskan siswa menjawab soal harus sesuai dengn contoh yang diberikan guru padahal siswa belum paham. Awalnya pada siklus 1 model pembelajaran yang digunakan pada penelitian ini secara klasikal/individual dengan asumsi siswa akan membuat ilustrasi gambar yang berbeda, tetapi ada beberapa siswa yang kurang tertarik dikarenakan siswa tersebut kurang dalam kemampuan spasial (gambar), kemudian pada siklus 2 model pembelajaran yang digunakan adalah model pembelajaran kooperatif tipe NHT. Selama proses pembelajaran siswa dapat bekerjasama, berinteraksi, berargumentasi, membuat gambar, bermain dan berkomunikasi tentang matematika. Pada pembelajaran dengan menggunakan model konvensional kemampuan siswa dalam berkomunikasi, berpendapat dan berargumentasi baik berupa lisan maupun tulisan sangat kurang, siswa hanya dituntut bisa mengerjakan soal-soal sesuai contoh. Sebagai indikator dapat diihat dari hasil wawancara, observasi dan hasil jawaban siswa.

\section{Hasil penelitian yang berkaitan dengan respon siswa}

Sesuai dengan pendapat Van Den Heuvel Panhuizen (1996), Ilustrasi diperlukan untuk menyertai suatu kontekstual. Peranannya adalah untuk memotivasi, menggambarkan situasi, menyiapkan informasi, mengidentifikasi action, mensuplai model, dan mengkomunikasikan solusi, serta strategi untuk solusi. Pada bagian pembahasan ini penulis akan membahas hasil penelitian daam kaitnnya dengan respon siswa setelah pembelajaran definisi logaritma berlangsung. Tanggapan siswa terhadap pembelajaran logaritma dengan menggunakan media ilustrasi gambar menunjukkan bahwa siswa merasakan senang. Hal ini disebabkan oleh beberapa alasan, misalnya hal ini di kemukakan oleh siswa pada hasil angket dan wawancara yaitu pembelajaran terasa menyenangkan karena terciptanya lingkungan relaks, tidak membuat stress, aman dan menarik, bahan ajar dan media 
digunakan relevan, melibatkan secara sadar semua indera dan juga pikiran otak kiri dan otak kanan, menantang bagi siswa untuk dapat berpikir jauh kedepan dan mengeksplorasi apa yang sedang dipelajari dengan kecerdasan yang relevan untuk memahami materi. Beberapa faktor yang merupakan alasan kuat bagi siswa untuk merasa senang dan tertarik pada pembelajaran logaritma dengan menggunakan ilustrasi gambar ini adalah tersedianya gambar yang menarik. Gambar dipandang sebagai ilustrasi yang mempunyai beberapa peran penting.

\section{KESIMPULAN}

Setelah melakukan serangkaian tahapan PTK dari hasil studi pendahuluan, membuat rencana tidakan, observasi dan analisis tindakan serta kegiatan refleksi selama 2 (dua) di kelas XII Bahasa, maka dapat disimpulkan bahwa: Penggunaan media ilustrasi gambar dapat meningkatkan pemahaman konsep dan respon siswa dalam pembelajaran definisi logaritma. Hal ini ditunjukkan yaitu, (1) Hasil rata-rata evaluasi dari jumlah siswa sebanyak 20 orang adalah 93,5 daya serap $100 \%$ dan $100 \%=20$ orang siswa sudah tuntas belajar mencapai KKM, (2) Berdasarkan hasil angket respon siswa dari jumlah 20 orang: menunjukkan sebagian besar siswa tertarik dengan pembelajaran logaritma dengan menggunakan media ilustrasi gambar, hampir semua siswa sangat tertarik pada materi pelajaran logaritma dengan menggunakan media ilustrasi gambar, sebagian besar siswa tertarik dengan berdiskusi dengan teman sekelompok atau sekelas memudahkan siswa menyeesaikan soal logaritma dengan menggunakan media ilustrasi gambar, hampir semua siswa menyatakan peran guru membantu siswa untuk bekerja secara mudah dan interaktif pada proses pembelajaran pemahaman definisi logaritma dengan menggunakan ilustrasi gambar, siswa menganggap sulit soal yang diberikan. Sebagian besar siswa menganggap tidak sulit soal yang diberikan, Tak seorangpun siswa menyatakan tidak aktif pada saat pembelajaran, dan sebagian besar siswa menyatakan sangat senang dengan pembelajaran pemahaman definisi logaritma dengn menggunakan media ilustrasi gambar, (3) Berdasarkan hasil wawancara dari jumlah responden 20 orang, (4) Penulis menarik kesimpulan dari hasil wawancara dengan responden kelompok atas, kelompok menengah dan kelompok bawah yaitu, siswa tertarik dengan media ilustrasi gambar pada pembelajaran logaritma ini, karena media ilustrasi gambar dapat membangkitkan keinginan dan minat baru,membangkitkan motivasi rangsangan kegiatan belajar dan bahkan membawa pengaruh psikologi terhadap siswa, serta membantu keefektifan proses 
pembelajaran dan penyampaian pesan pada pembelajaran saat itu (5) Penulis pun mendapat temuan dari hasil wawancara dengan seorang responden yang tergolong Anak Berkebutuhan Khusus (ABK) yang mengalami gangguan konsentrasi (ADHD) di kelas tersebut, ternyata penggunaan media ilustrasi gambar pada pembelajaran pemahaman definisi logaritma sangat cocok sehingga responden tersebut mendapat perolehan nilai yang luar biasa. Hasil perolehan pre-test 0 dan hasil perolehan nilai post test 90,25. Perolehan nilai seperti itu bukan hal biasa bagi siswa tersebut. Artinya penggunaan media ilustrasi gambar pada pembelajaran pemahaman definisi logaritma merupakan salah satu media pembelajaran yang dapat di gunakan bagi siswa berkebutuhan khusus.

\section{UCAPAN TERIMAKASIH}

Dalam melakukan penelitian tindakan kelas ini banyak sekali penulis mendapat bantuan yang tak ternilai dalam bentuk motivasi, untuk itu penulis ucapkan terimakasih kepada : Prof. Dr. Hj. R. Poppy Yaniawati, M.Pd. selaku pembimbing penelitian tindakan kelas, Kepala Sekolah SMAN 15 Bandung Bapak Drs. H.Hatta. Saputra, M.Si., Rekan guru pengamat Ibu Dra. Neneng Sutarsih, yang telah membantu pelaksanaan penelitian. Semua siswa kelas XII Program Bahasa di SMAN 15 Bandung serta emua pihak yang tidak dapat disebutkan satu persatu dalam kesempatan ini.

\section{REFERENSI}

Bobbi DePorter, Mark Reardon, \& Sarah Singer-Nourie, 2003. Mempraktikkan Quantum Learning di Ruang-Ruang Kelas. Quantum Teaching. Bandung Penerbit Kaifa Departemen Pendidikan Nasional. Model-Model Pembelajaran Yang Efektif.

Darta \& Saputra, J. (2018). Indicators that Influence Prospective Mathematics Teachers Representational and Reasoning Abilities. Journal of Physics: Conference Series 948 (1), 012053. DOI :10.1088/1742-6596/948/1/012053.

H. Eman Suherman., M.Pd, Dkk.2008 Metodologi Pembelajaran Matematika. Bandung. Panitia Sertifikasi Guru dalam Jabatan, Rayon Jawa Barat.

Patrianto, U., Sa 'dijah, C., \& Qohar, A. (2012). Penerapan Model Pembelajaran Kooperatif Tipe Think Pair Share untuk Memahamkan Materi Logaritma Kelas X Smkn 5 Malang, 1-9.

Saputra, J. (2013). Pengaruh Model Pembelajaran Edutainment dengan Pendekatan Somatic, Auditory, Visualization, And Intelectually (SAVI) terhadap Kemampuan Komunikasi Matematis Siswa SMA. SYMMETRY: Jurnal Pendidikan Matematika, 4 (1), 217-226.

Saputra, J. (2015a). Penggunaan Model Problem Based Learning Berbantuan E-Learning Dalam Upaya Meningkatkan Kemampuan Pemecahan Masalah Matematis dan Dampaknya terhadap Kemandirian Belajar Mahasiswa. Pasundan Journal of Mathematics Eduation Jurnal Pendidikan Matematika, 5 (2), 77-87. 
Saputra, J. (2015b). Program Maple untuk Meningkatkan Kemampuan Komunikasi Matematis Mahasiswa Calon Guru. SYMMETRY: Jurnal Pendidikan Matematika, 4 (2), 597-605.

Saputra, J. (2017a). The application of the Maple Program to Self-Regulated Learning on The Mathematics' Prospective Teachers Students. International Conference: Character Building Through Pricesly International Education Series 1 (1).

Saputra, J. (2017b). Penggunaan Model Problem Based Learning Berbantuan E-Learning Terhadap Kemandirian Belajar Mahasiswa pada Dimensi Tiga. KALAMATIKA \begin{tabular}{lllll}
\hline Jurnal Pendidikan & Matematika, & 2 & 117-130.
\end{tabular}

DOI: http://dx.doi.org/10.22236/KALAMATIKA.vol2no2.2017pp117-130

Saputra, J. (2017c). Kemampuan Self-efficacy pada Mahasiswa Tingkat Pertama Calon Guru Matematika. Prosiding Seminar Nasional Matematika dan Pendidikan Matematika, $\quad 5 \quad$ (5), $117 . \quad$ Tersedia di http://publikasi.stkipsiliwangi.ac.id/prosiding/prosiding-seminar-nasionalmatematika-dan-pendidikan-matematika-tahun-2017/

Thomas Armstrong, 2004. Sekolah Para Juara. Pakar Multiple Intelligensi. Menerapkan Multiple Intellegence di Dunia Pendidikan Bandung. Penerbit Kaifa.

Tim Pelatih Proyek PGSM 1999 Pendidikan dan Kebudayaan Direktorat Jenderal Pendidikan Tinggi Proyek Pengembangan Guru Penelitian Tindakan Kelas ( Classroom Reasearch ). Departemen Sekolah Menengah ( Secondary School Teacher Development Project ). Ibrd Loan no. 3979 Ind. 